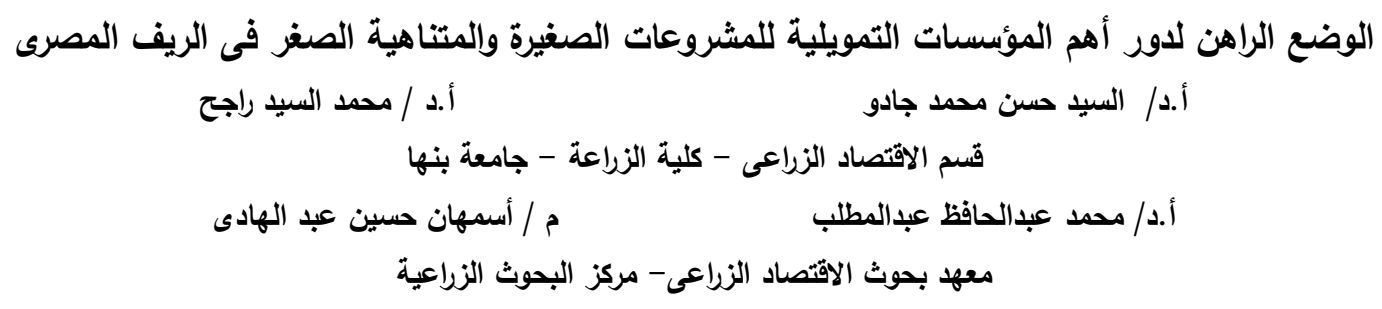

Corresponding author: asmahanhussein1234@gmail.com

مقدمه:

تمثل المشروعات الزراعية الصغيرة والمتتاهية الصغر أحد المكونات الهامة لبرنامج الإصلاح الاقتصادي الذي تقوم بتنفيذه الحكومة المصرية

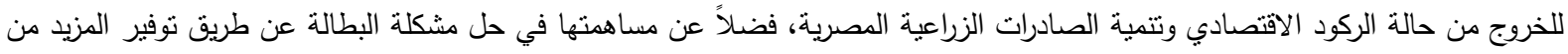

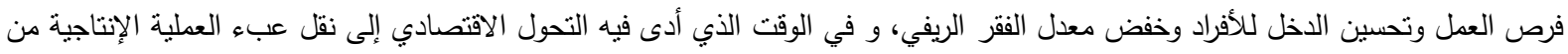

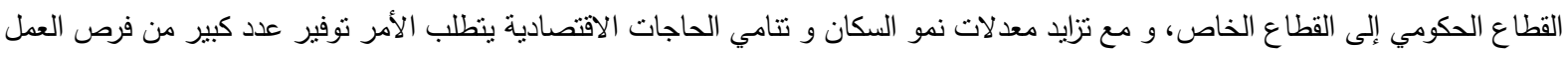
و زيادة الإنتاج، الأمر الذي أدى إلى زيادة الاهتمام بالمشروعات الزراعية الصغيرة والمتتاهية الصغر لكونها من أهم القطاعات الرئيسية في الزراعة المصرية ولأهميتها الاقتصادية الكبيرة.

مشكلة البحث:

تواجه الدوله العديد من المشاكل وخاصاً فى الاونه الاخيره حيث اصبحت مشكله البطاله وانخفاض الدخول الثخصيه من اهم المشاكل

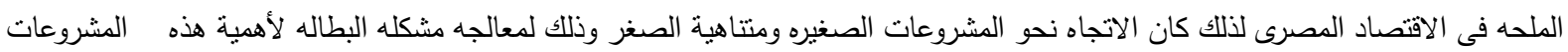

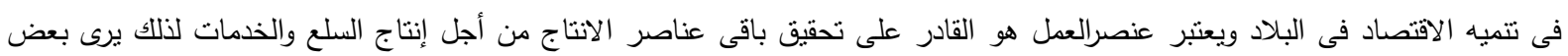
الاقتصاديين ان المشروعات الصغيره والمتتاهية الصغرهى السبيل الوحيد لحل هذه المشاكل التى لتى نعانى منها البلاد 0

هاف البحث :

يستهدف البحث بصفة أساسية إلى التعرف لدور أهم المؤسسات التمويلية للمشروعات الصغيرة والمتتاهية الصغر فى الريف المصرى ، وذللك من خلال دراسة الأهداف الفرعية التالية :تطور قيمة القروض المنصرفة من صندوف التتمية المحلية ، تقديرالمنصرف للمشروعات الصغيرة والمتناهية الصغرطبقاً للنطاق الجغرافى خلال الفترة 2009-2019 ، تحديد عدد المشرعات ومشروعات المرأة وعدد المستفيدين وفرص العمل 0

الطريقة البحثية ومصادر البيانات :

أعتمد البحث على أسلوب التحليل الوصفى والكمى للمتغيرات موضوع الدراسة لتوصيف المشكلة ومعرفة مكوناتها وتطورها ، كما تم استخدام أسلوب الاتحدار البسيط لتقدير الاتجاه الزمنى العام للمتغيرات موضع الدراسة. واعتمدت هذه الدراسة على البيانات الثانوية غير المنشورة من جهاز

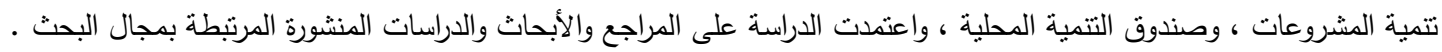

نتائج البحث

تطور قيمة القروض المنصرفة من صندوق التنمية المحلية للمشروعات الصغيرة والمتناهية الصغر خلال الفترة من (2008 - 2019) :

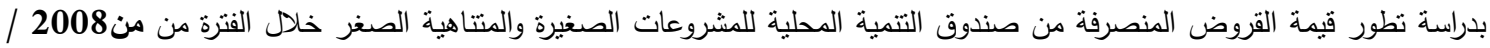
2009 2019 2019 ، ومن خلال بيانات الجدول(1) تبين للدراسة أن أعلى قيمة للقروض كانت فى سنة 2008 /2009 حيث بلغت قيمة القروض 32.96مليون جنيه وبأهمية نسبية بلغت 13.22\% ، يليها سنة 2012/2011 حيث بلغت قيمة القروض 30.29مليون جنيه وبأهمية

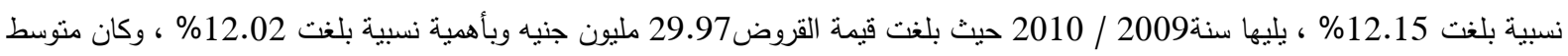

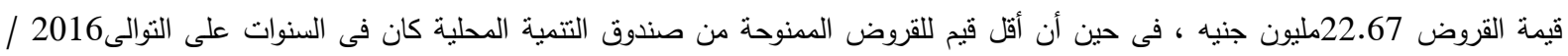

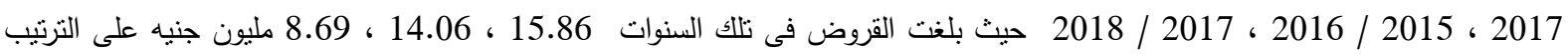

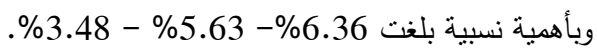
وبحساب معادلة الإتجاه الزمنى العام لإجمالى القروض المنصرفة من صندوق التنمية المحلية للمشروعات الصغيرة ومنتاهية الصغر خلاد الفترة من 2009/2008-2018 /2019 بالمليون جنيه تبين من المعادلة بالجدول رقم (2) ، أن القروض الممنوحة من صندوق النتمية المحلية 


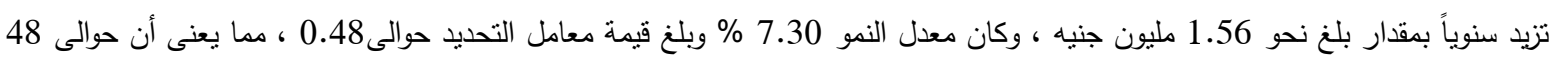

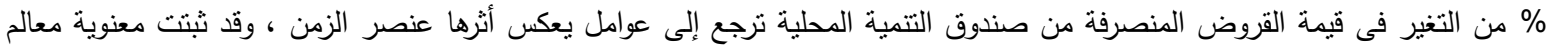
الإنحدار ومعنوية النموذج المستخدم وذللك عند مستوى معنوية الفرضية

جدول (1) قيمة القروض المنصرفة من صندوق التتمية المحلية على مستوى الجمهورية خلال الفترة (2008 - 2019 )

\begin{tabular}{|c|c|c|}
\hline الأهمية النسبية & قيمة القروض & السنة \\
\hline 13.22 & 32.96 & 2009 / 2008 \\
\hline 12.02 & 29.97 & $2010 / 2009$ \\
\hline 11.87 & 29.6 & $2011 / 2010$ \\
\hline 12.15 & 30.29 & $2012 / 2011$ \\
\hline 7.18 & 17.9 & $2013 / 2012$ \\
\hline 8.05 & 20.08 & $2014 / 2013$ \\
\hline 9.08 & 22.64 & 2015 / 2014 \\
\hline 5.63 & 14.06 & $2016 / 2015$ \\
\hline 6.36 & 15.86 & 2017 / 2016 \\
\hline 3.48 & 8.69 & $2018 / 2017$ \\
\hline 10.97 & 27.37 & 2019 / 2018 \\
\hline 100 & 249.42 & الإجمالى \\
\hline
\end{tabular}

جدول رقم (2) : معادلة الإتجاه الزمنى العام للقروض المنوحة للمشروعات الصغيرة والمتتاهية الممولة من صندوق التتمية المحلية خلال الفترة 2018-2008

\begin{tabular}{|c|c|c|c|c|c|}
\hline معدل النمو & المتوسط الحسابى & $\mathbf{F}$ & $\mathbf{R}^{2}$ & المعادلة & البيان \\
\hline$\% 7.30$ & 22.67 & 8.17 & 0.48 & $\begin{array}{c}Y=3355.11+1.65 X \\
(\mathbf{2 . 8 8})^{*} \quad(\mathbf{2 . 8 6})^{*}\end{array}$ & إجمالى القروض المنوحة \\
\hline
\end{tabular}

Y : إلى المتغير التابع وهى تمثل إجمالى المبالغ المنصرفة بالمليون جنيه من صندوق التتمية المحلية للمشروعات الصغيرة والمتتاهية خلال الفترة من 2009/20082019/2018 X : معامل التحديد. F معدل النمو : عبارة عن التغير السنوى/ المتوسط الحسابى للفترة × 100 ـ . القيمة بين القوسين :قيمة

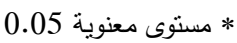
المصدر : بيانات الجدول رقم (1) وإستخدام البرنامج Excel 
جدول رقم (3) المشروعات التى نم الموافقة على تمويلها من صندوق التتمية المحلية ( موزعة على الأنشطة ) خلال الفترة من 01-01-2008-201

\begin{tabular}{|c|c|c|c|}
\hline 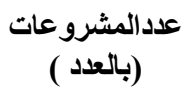 & جملة القروض (جنيه) & المحافظة & م \\
\hline 4 & 9000 & القاهرة & 1 \\
\hline 549 & 1821500 & الجيزة & 2 \\
\hline 1029 & 2974500 & القليوبية & 3 \\
\hline 222 & 584000 & الإسكندرية & 4 \\
\hline 1207 & 5277015 & البحيرة & 5 \\
\hline 994 & 5046000 & مطروح & 6 \\
\hline 5317 & 21068130 & المنوفية & 7 \\
\hline 5450 & 18903590 & الغربية & 8 \\
\hline 3773 & 20964400 & الدقهلية & 9 \\
\hline 2299 & 8408000 & كفر الشيخ & 10 \\
\hline 1327 & 5701200 & دمياط & 11 \\
\hline 408 & 2863000 & شمال سيناء & 12 \\
\hline 646 & 2864000 & الإسماعيلية & 13 \\
\hline 352 & 546500 & السويس & 14 \\
\hline 5179 & 20212540 & الشرقية & 15 \\
\hline 1643 & 6717200 & بنى سويف & 16 \\
\hline 8933 & 34218450 & المنيا & 17 \\
\hline 3477 & 11181200 & الفيوم & 18 \\
\hline 4900 & $\mathbf{1 7 5 8 2 0 0 0}$ & أسيوط & 19 \\
\hline 793 & 5247500 & الوادى الجديد & 20 \\
\hline 11122 & 42469800 & سوهاج & 21 \\
\hline 2673 & 11701440 & قنا & 22 \\
\hline 743 & 3610500 & أسوان & 23 \\
\hline 116 & 458000 & البحر الأحمر & 24 \\
\hline 4078 & 15748390 & الأقصر & 25 \\
\hline 67234 & 266177855 & & \\
\hline
\end{tabular}

المصدر : جمعت وحسبت من صندوق النتمبة المحلية ، بيانات غيرمنشورة 2019 .

كما يوضح الجدول رقم (4) والثكل رقم (1) والثكل رقم (2) بيان ورسم بيانى للنطاق الجغرافى ونصيب كل من المحافظات الحضرية ومحافظات الوجه البحرى والوجه القبلى وكذلك المحافظات الحدودية من إجمالى قيمة القروض وعدد المشروعات الممولة من صندوق التتمية المحلية

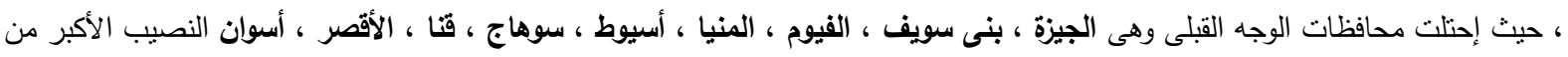
القروض وعدد المشروعات الممولة حيث بلغت قيمة القروض 145.05 مليون جنيه وبلغ عدد المشروعات 118 كشئ 3818 مشروع بأهية نسبية \% للقروض و 92.95 \% لعدد المشروعات المتاحة من القروض ، ثم جاء فى المرتبة الثانية محافظات الوجه البحرى وهى الدقهلية ، القليوبية ، الثرقية ، البحيرة ، الإسماعيلية ، المنوفية ، الغربية ، كفر الثيخ ، دمياط حيث بلغت قيمة القروض 106.37 مليون جنيه وبلغ عدد المشروعات 26227 مشروع بأهمية نسبية بلغته 39.96\% للقروض و 63.96 \% لعدد المشروعات المتاحة من القروض ، ثم جاءت المحافظات الحدودية فى المرتبة الثالثة وهى البحر الأحمر ، مطروح ، شمال سيناء ، الوادى الجديد حيث بلغت قيمة القروض 13.61 مليون جنيه وبلغ عدد المشروعات

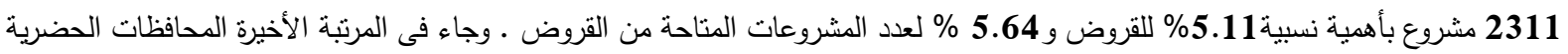

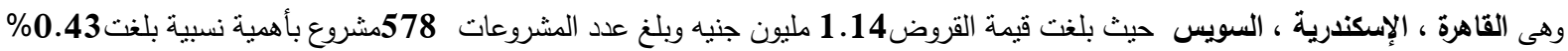

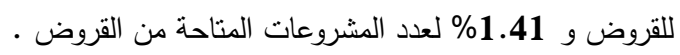


جدول رقم (4) المنصرف للمشروعات الصغيرة والمتتاهية الصغر طبقاً للنطاق الجغرافى خلال الفترة من 2008- 2019 ـ (القيمة بالمليون جنيه والمشروعات بالعدد)

\begin{tabular}{|c|c|c|c|c|}
\hline \% مشروعات & \% \% للقروض & عدد المشروعات & إجمالى المنصرف & البيان \\
\hline 1.41 & 0.43 & 578 & 1.14 & القاهرة ، الإسكندرية ، حضرية ، السويس \\
\hline 63.96 & 39.96 & 26227 & 106.37 & الغربية ، كفر الثيخ ، القليوبية ، الشرقية ، البحيرة ، الإسماعيلية ، المنوفية \\
\hline 92.95 & 54.49 & 38118 & 145.05 & الأقصزة ، أسوانى سويف ، الفيوم ، المنيا ، أسيوط ، سوهاج ، قنا ، \\
\hline 5.64 & 5.11 & 2311 & 13.61 & البحر الأحمر ، مطروح ، شمال سيناء ، الوادى الجديد \\
\hline 100 & 100 & 41007 & 266.18 & 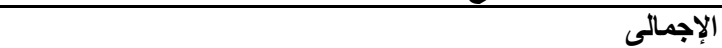 \\
\hline
\end{tabular}

المصدر :جمعت وحسبت من بيانات جدول رقم (3) .

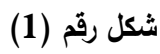

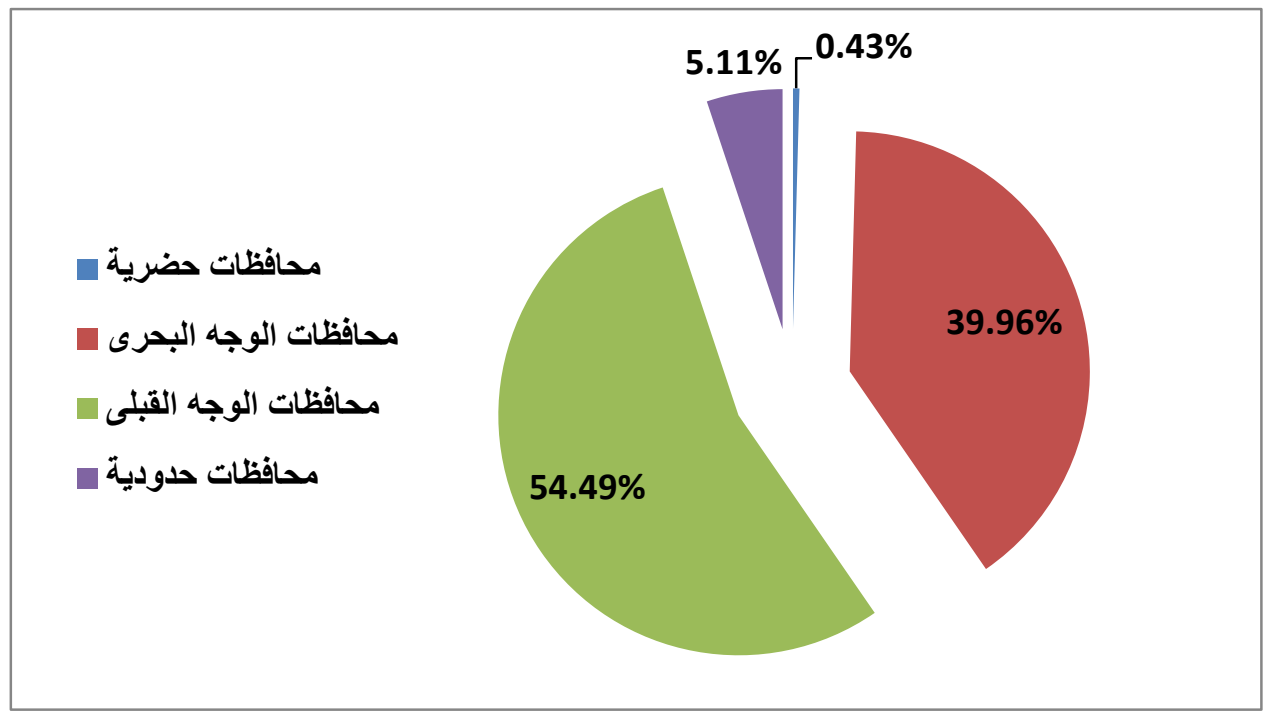

(3) المصدر : حسبت وجمعت من بيانات الجدول (2) (3)

شكل رقم (2) (2) (2)

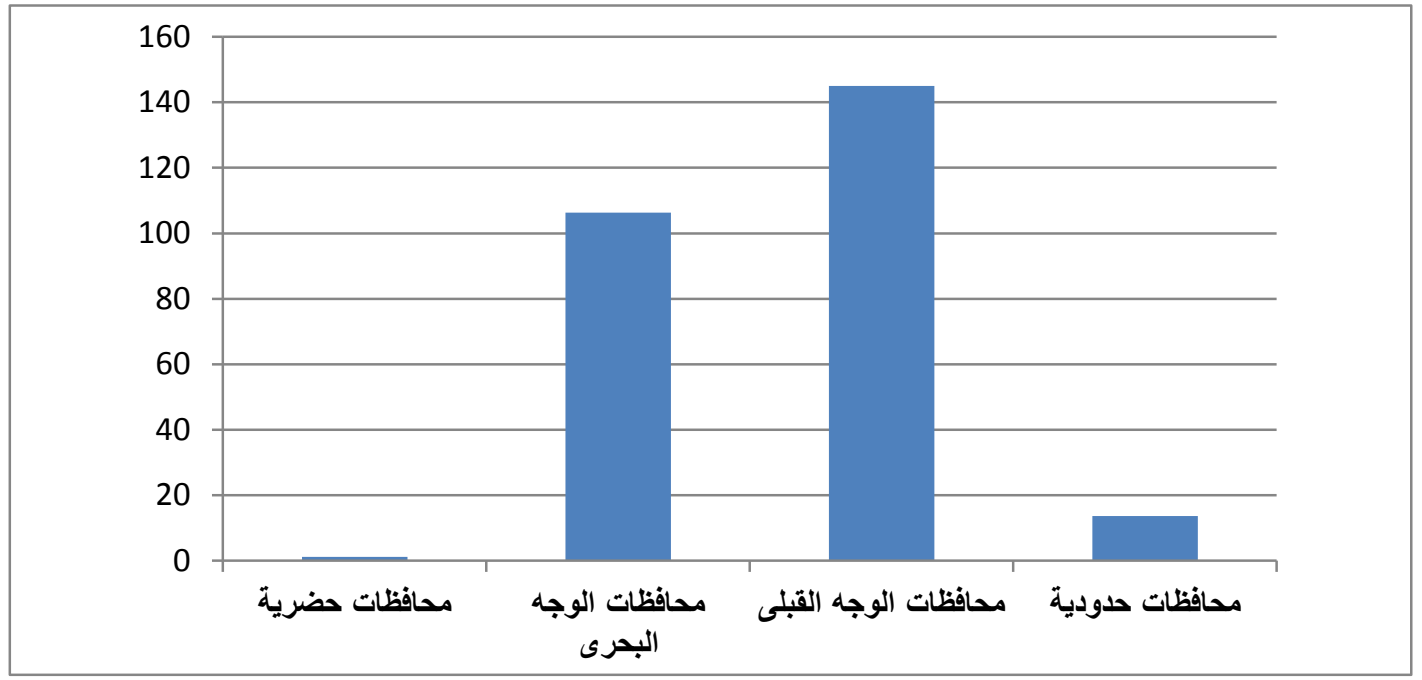


والجدول (5) يبين عدد المشروعات ومشروعات المرأة وعدد المستفيدين وفرص العمل الإضافية وقيمة القروض وفقاً لمجالات المشروعات المنفذة من خلال صندوق التتمية خلال الفترة 01-01-2008 إلى 30-6-2018 حيث كانت اكبر هذه المجالات من حيث عدد المشروعات هى نشاط الإنتاج الحيوانى حيث بلغ عدد المشروعات به نحو 49247 مشروعاً بنسبة 77.28 \% من جملة عدد المشروعات ، ويليها نشاط صناعات بيئية ومنزلية حيث بلغت عدد المشروعات نحو 2931 مشروعاً بنسبة 4.6\% ثم نشاط منافذ بيع ملابس ومفروشات 2593 مشروعاً بنسبة 4.07\% كما هن فى الثكل (3) ، ومن حيث عدد مشروعات المرأة فبلغت أقصاها فى نشاط الإنتاج الحيوانى أيضاً حيث بلغت بيئية ومنزلية حيث بلغ نحو 1999مشروعاً ثم نشاط منافذ بيع ملابس ومفروشات حيث بلغ نحو 1761مشروع كما فى الثكل (4) ، ومن حيث

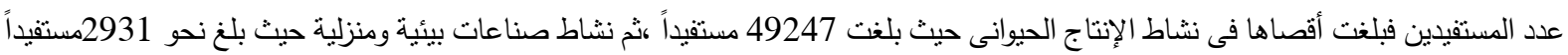
ثم منافذ بيع ملابس ومفروشات حيث بلغ نحو 2593 مستفيداً كما فى الثكل (5)، أما بالنسبة لعدد فرص العمل فقد بلغت أقصاها فى نشاط الإنتاج الحيوانى حيث بلغت نحو 49247 فرصة عمل ، ثم نشاط صناعات بيئية ومنزلية حيث بلغ نحو 2931 فرصة عمل ، ثم نشاط منافذ بيع ملابس ومفروشات حيث بلغ نحو فرصة عمل 2593 كما فى الثكل (6)، وبالنسبة لقيمة القروض فإن نشاط الإنتاج الحيوانى فى المركز الأول حيث بلغت قيمة القروض نحو 196230000جنيه بنسبة 82.16\%، ثم نشاط الميكنة الزراعبة حيث بلغ نحو 7441950 جنيه بنسبة 3.12\% ثم نشاط صناعات بيئية ومنزلية حيث بلغ نحو 6609400 جنيه جنيه بنسبة 2.77\% كما فى الثكل (7) .

جدول رقم (5) : عدد المشـروعات ومشروعات المرأة وعدد المستفيدين وفرص العمل وقيمة القروض بالجنية وفقاً لمجالات المشـروعات المنفذة من

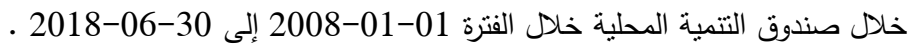

\begin{tabular}{|c|c|c|c|c|c|c|c|}
\hline \% القروض & جملة القروض & إجمالى فرص العمل & المستفيدين & مشروعات & \% المشروعات & المشروعات & النشاط \\
\hline 0.41 & 989000 & 642 & 642 & 581 & 1.01 & 642 & لحوم بيضاء \\
\hline 82.16 & 196230000 & 49247 & 49247 & 28225 & 77.28 & 49247 & إنتاج حيوانى \\
\hline 0.16 & 383000 & 142 & 142 & 83 & 0.22 & 142 & عسل النحل ومنتجاته \\
\hline 0.15 & 357200 & 128 & 128 & 92 & 0.2 & 128 & منتجات الألبان \\
\hline 0.01 & 21000 & 10 & 10 & 7 & 0.02 & 10 & صناعات زراعية - عيش غراب \\
\hline 3.12 & 7441950 & 1545 & 1545 & 812 & 2.42 & 1545 & ميكنة زراعية \\
\hline 1.02 & 2443380 & 67 & 67 & 2 & 0.11 & 67 & وسائل نقل ركاب ويضائع \\
\hline 2.77 & 6609400 & 2931 & 2931 & 1999 & 4.6 & 2931 & صناعات بيئية ومنزلية \\
\hline 0.94 & 2249325 & 414 & 414 & 132 & 0.65 & 414 & ورش ومصانع \\
\hline 2.3 & 5484700 & 2349 & 2349 & 1533 & 3.69 & 2349 & منافذ بيع مواد غذائية \\
\hline 0.41 & 988200 & 298 & 298 & 232 & 0.47 & 298 & مضارب ومطاحن صغيرة \\
\hline 0.19 & 463300 & 94 & 94 & 68 & 0.15 & 94 & وحدات خبيز منزلية \\
\hline 0.06 & 138000 & 56 & 56 & 30 & 0.09 & 56 & مطاعم وكافتيريات \\
\hline 2.5 & 5982000 & 2593 & 2593 & 1761 & 4.07 & 2593 & منافذ بيع ملابس \\
\hline 0.03 & 60000 & 19 & 19 & 10 & 0.03 & 19 & زراعات غير تقليدية \\
\hline 1.08 & 2584000 & 987 & 987 & 517 & 1.55 & 987 & منافذ بيع سلع وأجهزة \\
\hline 0.95 & 2276500 & 934 & 934 & 514 & 1.47 & 934 & بيع اعلاف واسمدة وغلال \\
\hline $\mathbf{0}$ & 8000 & 3 & 3 & 1 & $\mathbf{0}$ & 3 & حاسبات الية \\
\hline 0.58 & 1391550 & 423 & 423 & 249 & 0.66 & 423 & مكتبات - ماكينات تصوير \\
\hline 0.24 & 579000 & 258 & 258 & 178 & 0.4 & 258 & صناعات غذائية \\
\hline 0.9 & 2146850 & 584 & 584 & 281 & 0.92 & 584 & أخرى \\
\hline 100 & 238826355 & 63724 & 63724 & 37307 & 100 & 63724 & الإجمالى \\
\hline
\end{tabular}

المصدر : وزارة التتمية المحلية ، صندوق التتمية المحلية ، بيانات غير منشورة 2019 . 


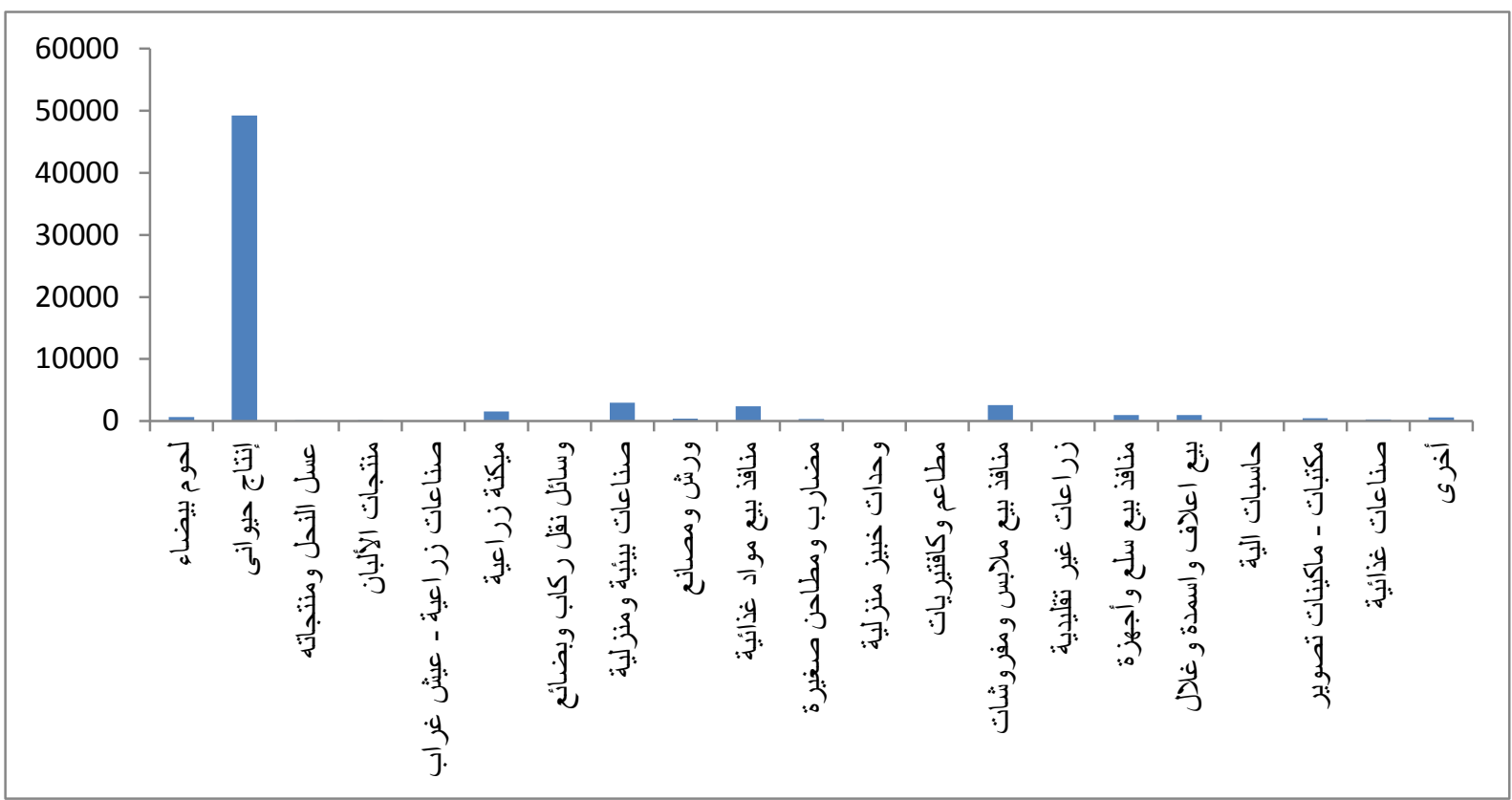

شكل (3) عدد المشروعات الممولة من صندوق التمية المحلية موزعة على الأنشطة المختلفة

المصدر : بيانات جدول (5) (د)

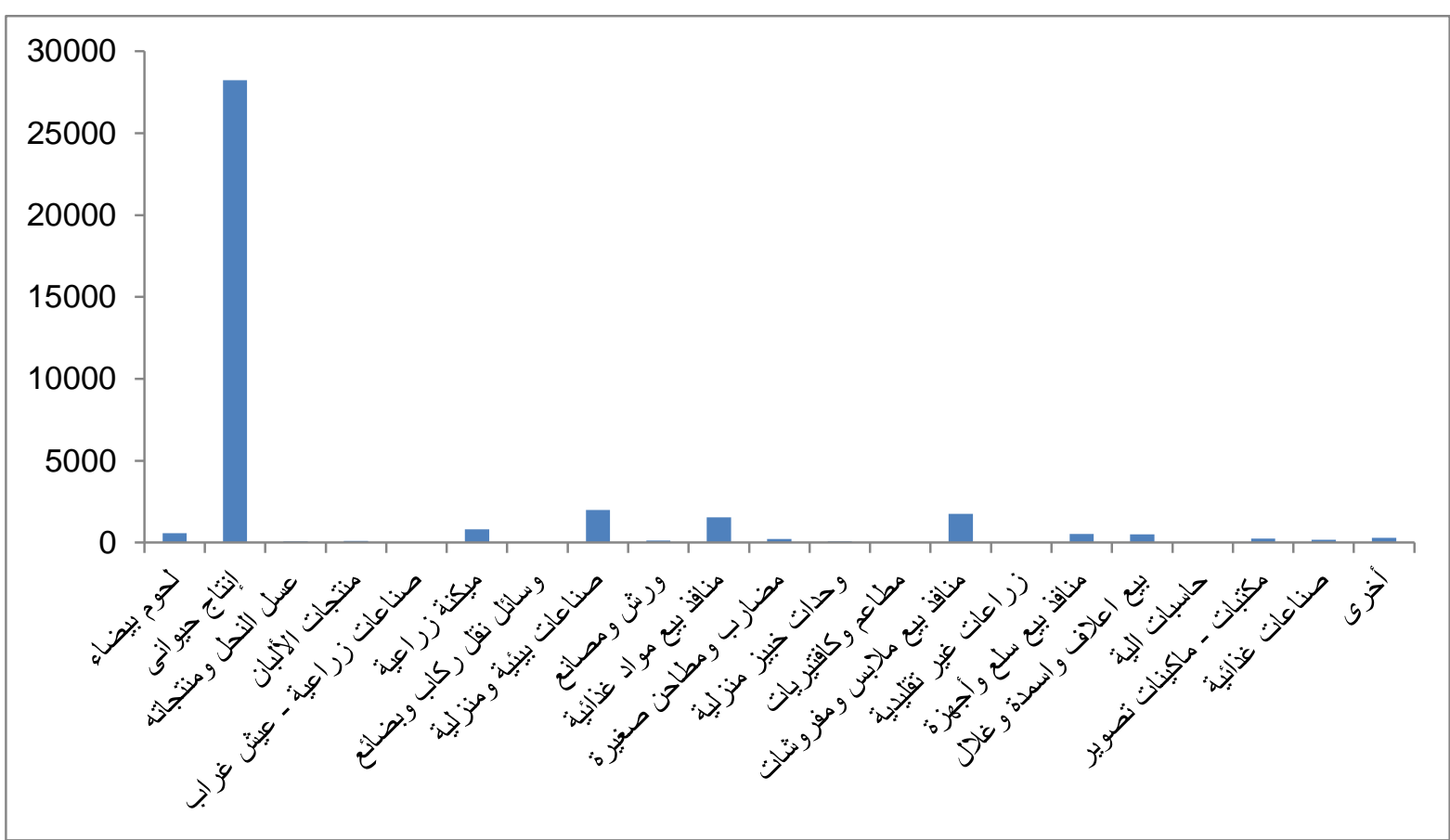

شكل (4) عدد المشروعات المرأة الممولة من صندوق التتمية المحلية موزعة على الأنشطة المختلفة

المصدر : بيانات جدول (5) المترعات 


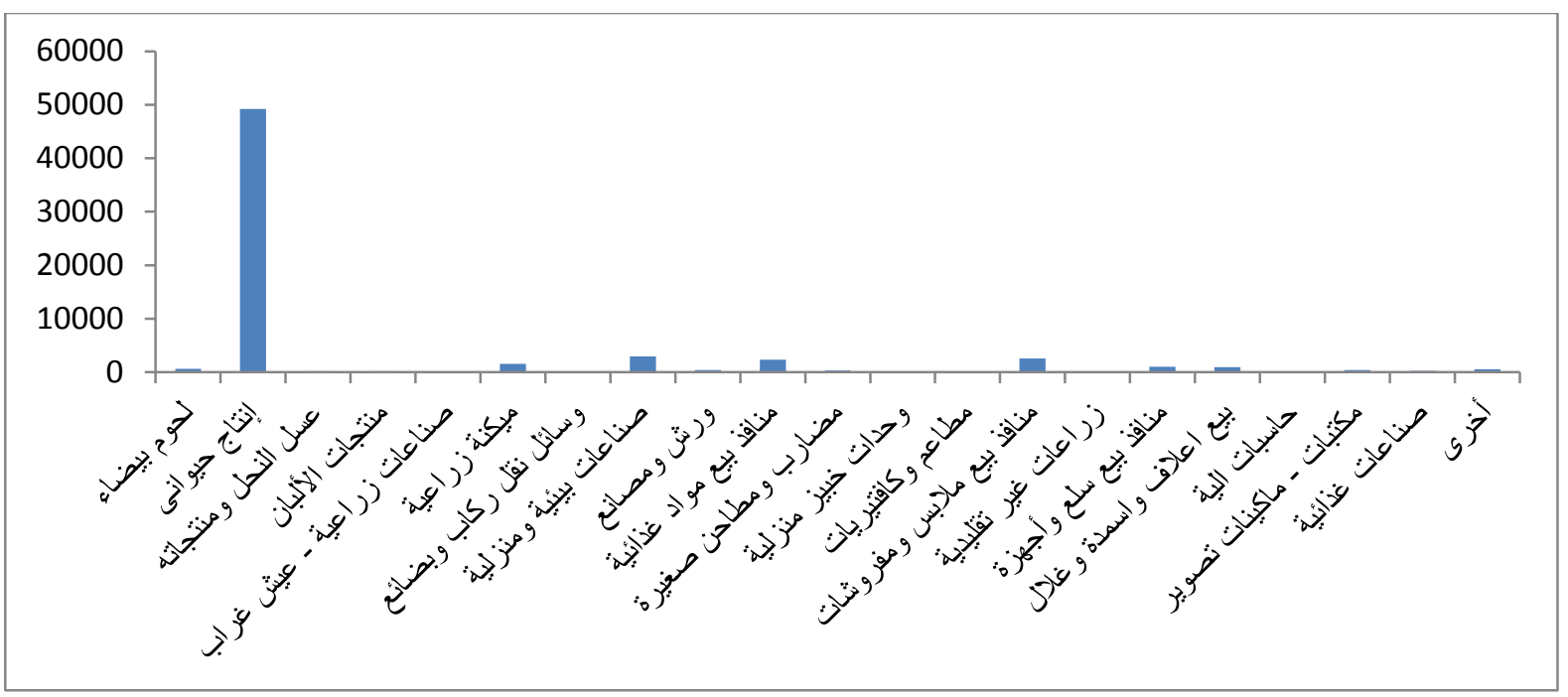

شكل (5) عدد المستقيدين من المشروعات الممولة من صندوق التتمية المحلية موزعة على الأنشطة المختلفة

المصدر : بيانات جدول (5) (5)

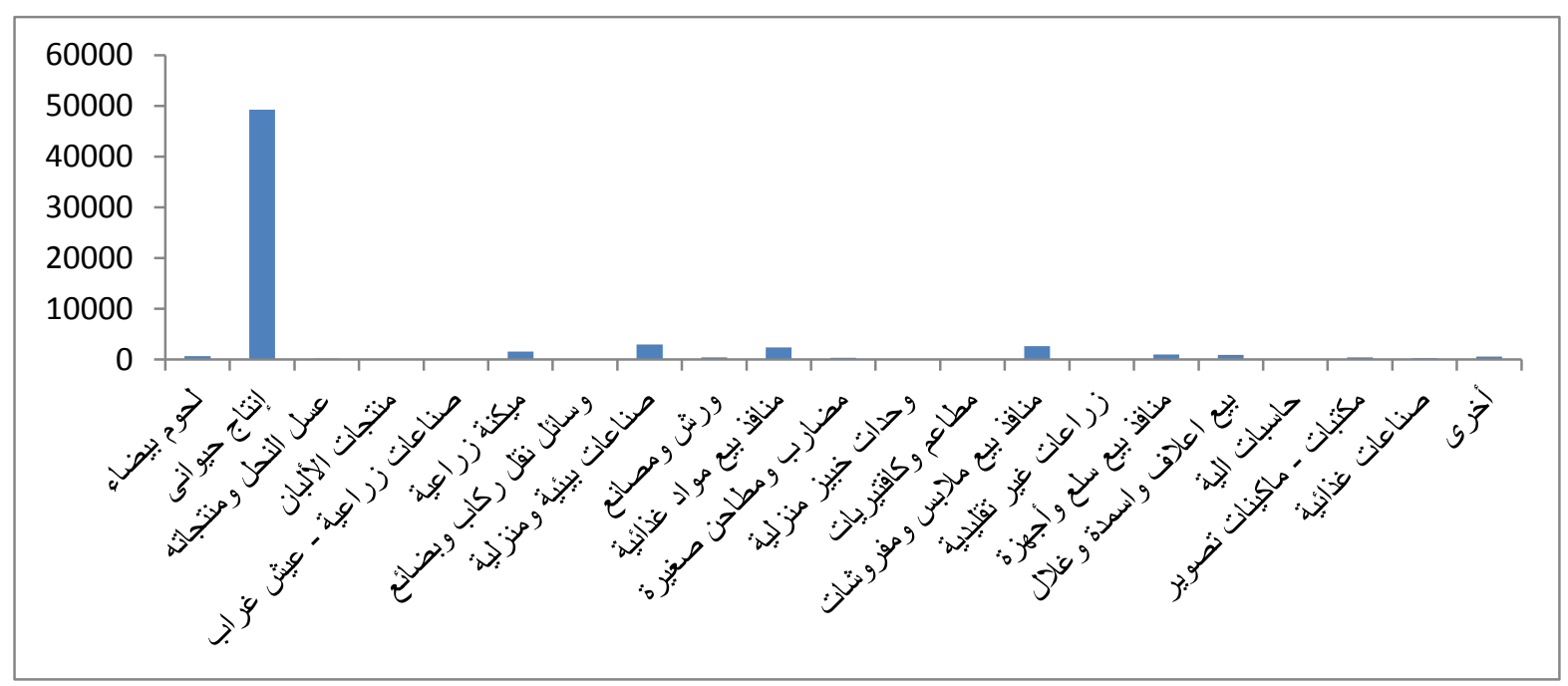

شكل (6) عدد فرص العمل المتوفرة من المشروعات الممولة من صندوق التنمية المحلية موزعة على الأنشطة المختلفة

المصدر : بيانات جدول (5) (10)

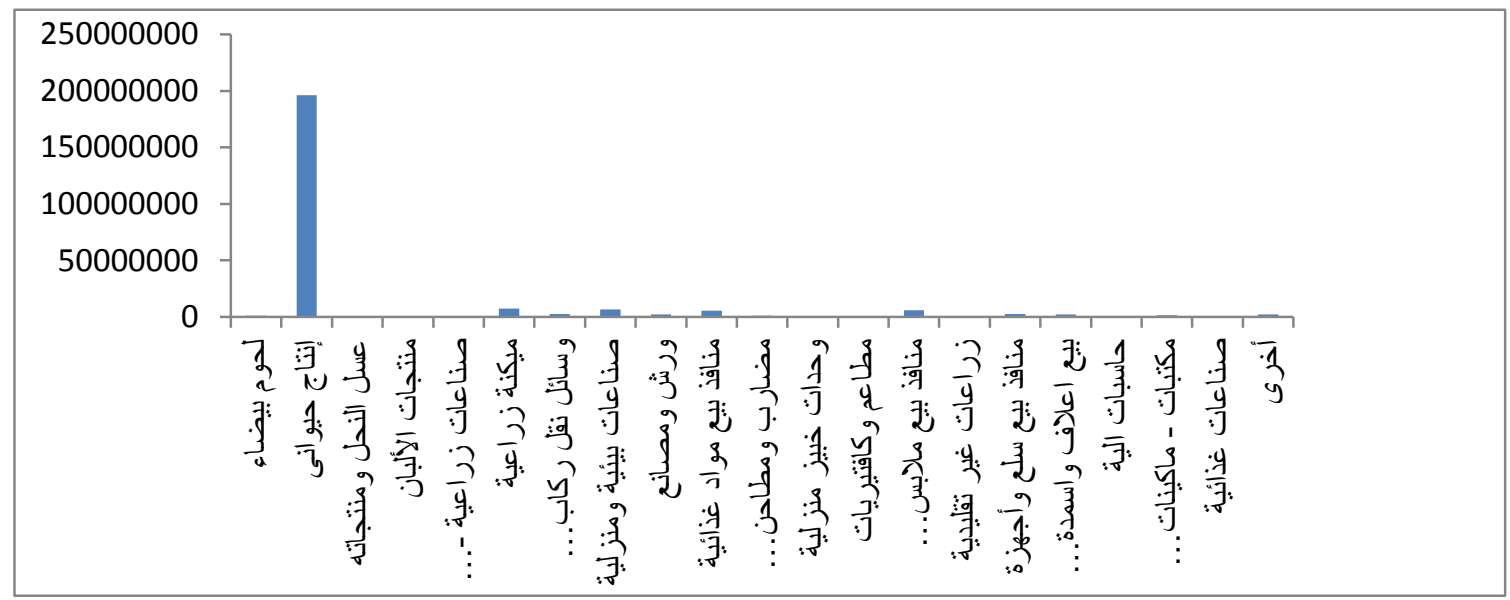

شكل (7) قيمة القروض الممنوحة من صندوق التنمية المحلية موزعة على الأنشطة المختلفة

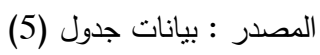


تمثل المشـروعات الزراعية الصــغيرة والمتتاهية الصــغر أحد المكونات الهامة لبرنامج الإصــلاح الاقتصــادي الذي تقوم بتتفيذه الحكومة

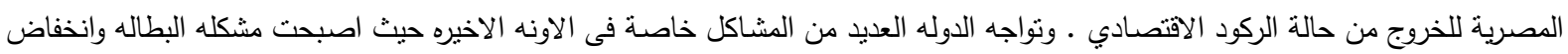

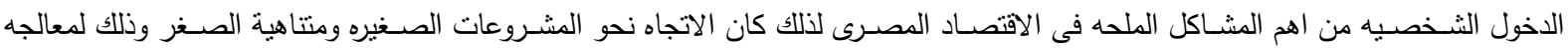

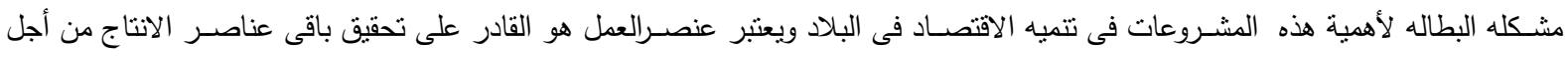

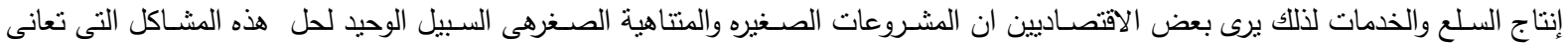
منها البلاد .

استهدف البحث بصفة أساسية إلى التعرف لدور أهم المؤسسات التمويلية للمشروعات الصغيرة والمتتاهية الصغر فى الريف المصرى ، وذلك من خلال دراسة الأهداف الفرعية الثالية :تطور قيمة القروض المنصرفة من صندوق التتمية المحلية ، تقديرالمنصرف للمشروعات الصغيرة

والمتتاهية الصغرطبقاً للنطاق الجغرافى خلال الفترة 2009-2019 ، تحديد عدد المشرعات ومشروعات المرأة وعدد المستفيدين وفرص العمل.

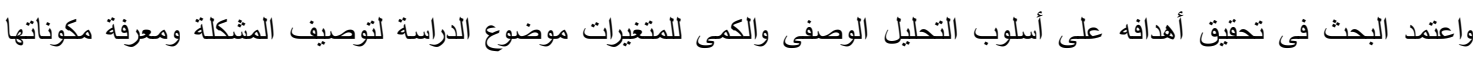
وتطورها ، كما نم استخدام أسلوب الانحدار البسيط لتقدير الاتجاه الزمنى العام للمتغيرات موضع الدراسة.

أهم النتائج التى تم التوصل إليها :1- توصلت الدراسة إلى أن المحافظات الحضرية جاءت أهميتها النسبية فى ذيل القائمة بالنسبة لقيمة القروض المنصرفة من صندوق التتمية المحلية خلال فترة الدراسة حيث بلغت الأهمية النسبية لعدد المشروعات 1.41. 1. 2- توصلت الدراسة أن إجمالى قيمة القروض الممنوحة من صندوق التتمية المحلية قد بلغ 249.42مليون جنيه وقد بلغت القروض حدها الأقصى

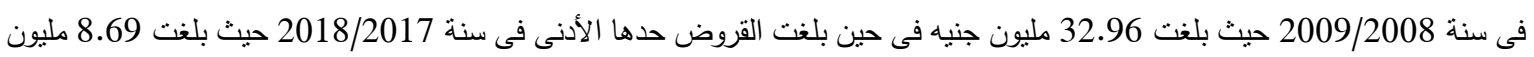
جنيه وكان متوسط إجمالى القروض 22.67 مليون جنيه .

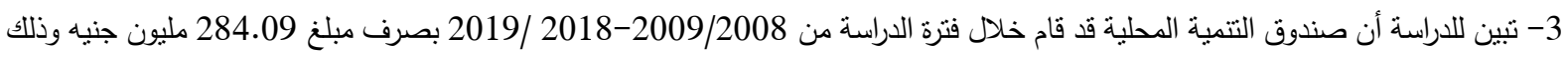
لتمويل عدد 95520 مشروع ، وكان عدد المستفيدين 100412 مستقيد منهم 102103 ذكور ومنهم 53430 إناث ، وقد بلغت قيمة الإستثمارات

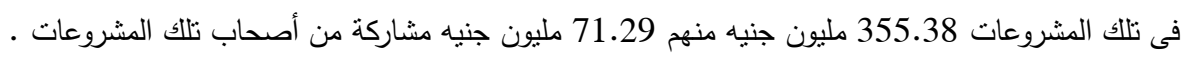
4- تبين للاراسة أن أعلى قيمة للقروض الممنوحة من صندوق التنمية المحلية كانت فى سنة 2008 / 2009 حيث بلغت قيمة القروض 32.96

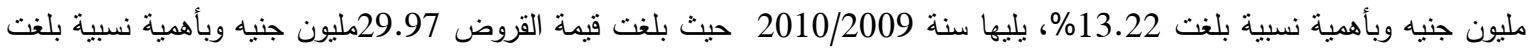
12.02 \% ، يليها سنة 2011/2010 حيث بلغت قيمة القروض 29.60مليون جنيه وبأهمية نسبية بلغت 11.87\% ، وكان منوسط قيمة القروض 22.67 مليون جنيه ، فى حين أن أقل قيم للقروض المدنوحة من صندوق التتمية المحلية كان فى السنوات 2016 ، 2016 / / 2017 ، 2015 ، 2018 ، 2015

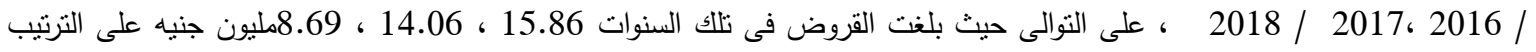

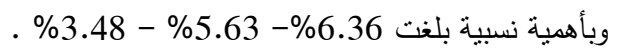
5- توصلت الدراسة إلى أن عدد المشروعات ومشروعات المرأة وعدد المستقيدين وفرص العمل الإضافية وقيمة القروض وفقاً لمجالات المشروعات المنفذة من خلال صندوق التتمية خلال الفترة 01-01-2008 إلى 30-6-2018 حيث كانت اكبر هذه المجالات من حيث عدد المشروعات هى نشاط الإنتاج الحيوانى حيث بلغ عدد المشروعات به نحو 49247 مشروعاً بنسبة 77.28 \% من جملة عدد المشروعات ، ويليها نشاط

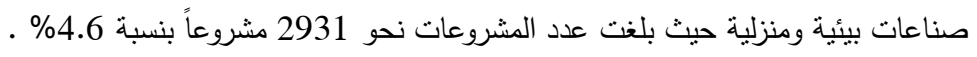

1- الاهتمام بتشجيع التوسع في المشروعات الزراعية الصغيرة والمتتاهية الصغر بغرض توفير فرص عمل لثباب الخريجين ورفع مستوى المعيشة فى الريف المصرى. 2- تفعيل دور الجهات الممولة للمشروعات الزراعية الصغيرة والمتتاهية الصغر وذلك من خلا تقديم العديد من التسيلات الائتمانية وتقديم فروض ميسرة الدفع. 3- تقديم الاستثارات الفنية والاقتصادية التي تساعد أصحاب المشروعات الصغيرة على التغلب على المعوقات التي تواجههم أثناء وبعد إقامة تلك المشروعات الأخرى محل الدراسة.

4- تفعيل دور السياسات التسويقية بما يضم تسويق منتجات المشروعات الصغيرة والمتتاهية وحمايتهم من اسغلال التجارمع احكام الرقابة عليهم 0

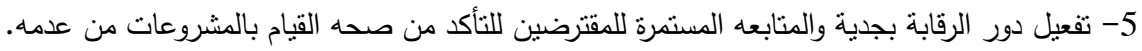


6- التكامل بين المشروعات الصغيره والمتتاهيه الصغر والمتوسطه والكبيره داخل كل محافظة. 7- إقامة مراكز لتدريب الثباب على المشروعات الصغيرة والمتتاهية الصغر .

8- إقامة منافذ لبيع منتجات المشروعات الصغيره والمتتاهيه الصغربكل محافظة .

1- جمال عبد الحكيم محمود محمد سعد ، المشروعات الزراعية الصغيرة والمتوسطة وأثرها على التنمية الإقتصادية ، رسالة ماجستير ،

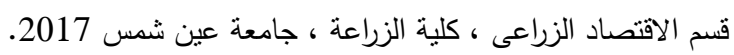

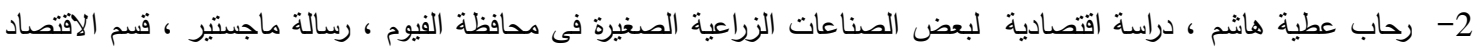

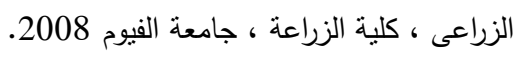

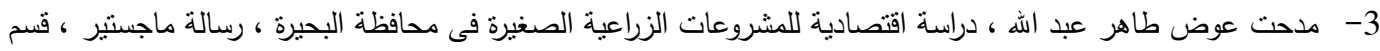

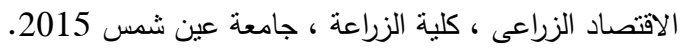

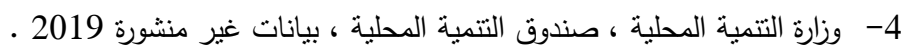




\section{The Current Status of the Role of the Most Important Microfinance Institutions in Rural Egypt}

ELSayed Hassan Mohammed Gado ${ }^{1}$ - Mohamed Elsayed Rageh ${ }^{1}$ Mohamed Abd Elhafez Abd Elmotalib ${ }^{2}$ Asmahan Hussein AbdElhady ${ }^{2}$

${ }^{1}$ Department of Agricultural Economics - Faculty of Agriculture- Benha University

${ }^{2}$ Agricultural Economics Research Institute, Agric. Res. Center.

\section{Summary}

Program being implemented by the Egyptian Small and micro-agricultural enterprises are an important component of the economic reform government to break the economic downturn.

The state faces many problems, especially in recent times, where the problem of unemployment and low personal incomes has become one of the most pressing problems in the Egyptian economy. The elements of production in order to produce goods and services, therefore, some economists believe that small and micro enterprises are the only way to solve these problems plaguing the country.

The main objective of this research was to identify the role of the most important microfinance institutions in the Egyptian countryside by studying the following sub-objectives: Evolution of the value of loans disbursed from the Local Development Fund, estimating the disbursement of small and micro enterprises according to the geographical scope during the period 2009-2019, determining the number of Legislations, Women's Projects, Number of Beneficiaries and Job Opportunities.

The research relied on the method of descriptive and quantitative analysis of the variables of the study to describe the problem and knowledge of its components and evolution. A simple regression method was used to estimate the overall time trend of the variables under study.

The most important results that have been tried- :

1-The study found that the provinces in urban areas.

2. The study found that the total value of loans granted by the Local Development Fund reached LE 249.42 million Loans reached a maximum of LE 32.96 million in 2008/2009, while loans reached a minimum of LE 8.69 million in 2017/2018, with an average of LE 22.67 million.

3- The study showed that the local development fund has spent 284.09 million pounds during the study period from 2008 / 2009-2018 / 2019 to finance 95520 projects. The number of beneficiaries was 100412 beneficiaries including 42103 males including 53430 females.

The value of investments in these projects amounted to 355.38 million pounds, of which 71.29 million pounds participation of the owners of these projects.

4- The study showed that the highest value of loans granted by the Local Development Fund was in 2008/2009 with a value of LE 32.96 million with a relative importance of $13.22 \%$, followed by 2009/2010 with a value of LE 29.97 million and a relative importance of $12.02 \%$.

The value of loans amounted to LE 29.60 million, with a relative importance of $11.87 \%$. The average value of loans was LE 22.67 million, while the lowest value of loans granted by the Local Development Fund was in 2016/17, 2015/2016 and 2016. Loans in those years amounted to 15.86, 14.06 and 8.69 million pounds respectively, with a relative importance of $6.36 \%-5.63 \%-3.48 \%$.

5- The study found that the number of projects and projects of women and the number of beneficiaries and additional employment and the value of loans according to the fields of projects implemented through the Development Fund during the period 01-01-2008 to 30-6-2018, where the largest of these areas in terms of the number of projects is the activity of animal production where the number of projects with about 49247 projects $77.28 \%$ of the total number of projects, followed by the activity of environmental and household industries where the number of projects amounted to 2931 projects by $4.6 \%$.

\section{Recommendations:}

1- Encouraging the expansion of small and micro agricultural projects in order to provide job opportunities for young graduates and raise the standard of living in the Egyptian countryside.

2- Activating the role of the financiers of small and micro agricultural projects through providing many credit facilities and providing easy loans.

3- Providing technical and economic consultations that help small business owners to overcome the obstacles they face during and after the establishment of these other projects under study.

4- Activating the role of marketing policies, including marketing of products of small and micro enterprises and protect them from the exploitation of merchants with the provisions of control over them.

5- Activate the role of control seriously and follow-up of the borrowers to ensure the correctness of doing projects or not.

6- Integration of small, small, medium and large projects within each governorate.

7- Establishing centers for training young people on small and micro projects

8- Establishing outlets for the sale of products of small and micro projects in the province of each province 